\title{
MAKNA INTERAKSI DALAM KOMUNIKASI \\ (Teori Interaksi Simbolik Dan Teori Konvergensi Simbolik)
}

\author{
Suheri \\ Mahasiswa Doktoral Program Pasca Sarjana \\ Universitas Islam Negeri Sumatera Utara
}

\begin{abstract}
Abstrak
Berkembanganya konsep interaksi dan komunikasi sering dipergunakan tetapi mungkin diartikan secara berbeda-beda. Pada kenyataanya konsep interaksi akan berkembang menjadi interaksi social dan berujung pada aktivitas berupa komunikasi dan melalui komunikasi individu akan merasakan kepuasan, kesenangan atau mendapatkan pengetahuan (informasi) yang akan menunjang terhadap perkembangan individu. Selanjutnya interaksi simbolik juga tidakbisa dilepaskan dari proses komunikasi, karena awalnya maknaitu tidak ada artinya, sampai pada akhirnya di konstruksi secarainterpretif oleh individu melalui proses interaksi, untukmenciptakan makna yang dapat disepakati secara bersamadimana asumsi-asumsi itu adalah sebagai berikut: Manusia bertindak terhadap manusia lainnyaberdasarkan makna yang diberikan orang lain kepadamereka serta konvergensi simbolik didasarkan pada gagasan bahwa para anggota dalam kelompok harus bertukar fantasi dalam rangka untuk membentuk kelompok yang kohesif artinya individu terlibat dalam berkomunikasi untuk bertukar pengalaman-pengalaman.
\end{abstract}

Kata Kunci: Interaksi, Komunikasi,

\section{A. Pendahuluan}

Kemunculan Symbolic Convergence Theory (CST) atau dalam bahasa Indonesia menjadi Teori Konvergensi Simbolik (TKS) diilhami dari riset Robert Bales mengenai komunikasi dalam kelompok-kelompok kecil. Pada penelitian yang dilakukan tahun 1950-an tersebut, Bales sebenarnya memfokuskan penyelidikannya pada perilaku anggota kelompok.

Namun dalam proses tersebut, Bales menemukan kenyataan lain yang menarik minatnya. Yakni, adanya kecenderungan anggota-anggota kelompok menjadi dramatis dan berbagi cerita, ketika kelompok mengalami ketegangan. Menurut Bales cerita-cerita tersebut diantaranya meliputi lelucon, kisah, ritual, perumpamaan atau permainan kata-kata, yang ternyata memiliki fungsi penting dalam mengurangi ketegangan kelompok (tension release), bahkan mampu meningkatkan kesolidan kelompok. Robert Bales menyebutnya fenomena Fantasy Theme yang muncul ketika individu menjadi tegang dan menjadi dramatis dan 
berbagi cerita. Tema ini merupakan bagian dari tema yang lebih luas dan rumit yang disebut visi retoris. (Venus, 2007)

Tema ini intinya sebuah tinjauan bagaimana sesuatu itu terjadi, sedang dan akan terjadi. Tema dan visi terdiri dari orang atau karakter. Memiliki alur cerita sebagai aksi atau pengembangan dari cerita itu. Adegannya adalah kumpulan pergaulan socialkultural. Agen pendukung sebagai sumber yang mensyahkan cerita itu. Ernest Bormann meminjam gagasan tersebut untuk direplikasi ke dalam tindakan retoris masyarakat dalam skala yang lebih luas dari sekedar proses komunikasi kelompok kecil. Penelitian-penelitian Bormann secara intensif sepanjang tahun 1970-an lantas bermuara pada munculnya Teori Konvergensi Simbolik.

Pertama kali teori ini disampaikan oleh Ernest Bormann dalam tulisannya yang bertajuk : The yang diterbitkan dalam Quarterly Journal of Speech 1972. Bormann juga menulis ratusan artikel dan laporan penelitian yang menggunakan TKS sebagai landasan teoritisnya, berikut Fantasy Theme Analysis (FTA) sebagai metodenya dengan berfokus pada kohesivitas dan budaya kelompok, politik, hingga kampanye politik. Tulisan Borman lainnya yang secara khusus dan lengkap berbicara tentang TKS adalah Con yang dimuat dalam

Journal of Communication, tahun 1985. Ernest Bormann's menawarkan metode yang menjanjikan untuk melihat interaksi kelompok kecil dan kepaduan. Ketika orangorang yang tidak mengenal satu sama lain datang bersama demi mencapai tujuan bersama, baik kelompok dalam sebuah organisasi atau siswa mengerjakan tugas sekolah, teori konvergensi simbolik dimengerti dan secara umum melihat sikap secara akurat tentang bagaimana kekompakan di dalam kelompok tercapai. Teori konvergensi simbolik banyak dipuji dan dianggap agak tidak biasa, karena memenuhi kriteria ilmiah dan humanistik standar. TKS dapat dipercaya karena memenuhi "tujuan kembar pengetahuan ilmiah" (Littlejohn,2002) Teori Bormann memenuhi standar ilmiah penjelasan tentang hasil, relatif sederhana, dan kegunaan praktis.

Teori konvergensi simbolik didasarkan pada gagasan bahwa para anggota dalam kelompok harus bertukar fantasi dalam rangka untuk membentuk kelompok yang kohesif. Dalam teori ini, sebuah fantasi tidak merujuk pada cerita-cerita fiktif atau keinginan erotis.

Fantasi adalah cerita atau lelucon yang mengandung atau mengungkapkan emosi. Fantasi meliputi peristiwa dari seorang anggota kelompok di masa lalu, atau peristiwa yang mungkin terjadi di masa depan. Fantasi tidak mencakup komunikasi yang berfokus pada apa yang terjadi di dalam kelompok. Sebagai contoh, Bob adalah anggota dari sebuah tim di 
sebuah biro iklan dan menampilkan ide untuk kemungkinan iklan. Bob tidak mengungkapkan sebuah fantasi, karena ia membahas pekerjaan yang sedang ditangani. Namun, jika Bob mengakui bahwa ia pergi berbelanja setelah pulang kerja untuk membeli sepeda anaknya untuk ulang tahunnya yang ketujuh, maka ia telah mengungkapkan fantasi.

Sebuah Reaksi rantai fantasi positif dan energik terhadap fantasi awal. Ketika Bob menyebut anaknya ulang tahun, beberapa anggota kelompok lainnya menambahkan bagaimana mereka harus menghadiri pertandingan sepak bola putra mereka setelah bekerja, Suasana di lingkungan kerja telah berubah dari serius menjadi nyaman dan bahkan energik. Ketika Bob menyebut anaknya ulang tahun, khayalan reaksi berantai telah dinyalakan.

Fantasi lain muncul tentang anak-anak, permainan sepak bola, dan ulang tahun Kohesi dalam suatu kelompok bukan merupakan bentuk tindakan yang segera. Sebuah peristiwa rantai fantasi tidak akan menghasilkan kohesi lengkap. Dalam contoh di atas, maka ada kemungkinan bahwa seorang anggota kelompok atau anggota tidak punya anak dan dengan demikian tidak akan terlibat dalam percakapan. Fantasi mereka belum diungkapkan pada saat itu, sehingga kesamaan belum terbentuk antara semua anggota kelompok. Secara umum, berbagai fantasi akan diekspresikan selama kegiatan kelompok, sehingga dikecualikan sebelumnya anggota yang dapat menemukan dasar yang sama dalam berhubungan dengan anggota kelompok lainnya. Menciptakan kohesi dalam kelompok membutuhkan waktu, karena mengenali kesamaan dan mengembangkan suasana yang nyaman berlangsung secara bertahap dan merupakan proses kelompok kritis yang harus bertahan.( Young, 1998)

Menurut Griffin, "konvergensi melalui simbol, individu-individu membangun rasa komunitas atau kesadaran kelompok (Griffin, 1991 : 34).Sebagai konvergensi simbolik ikatan kelompok secara kohesif memiliki rasa kebersamaan yang terbentuk. Masingmasing anggota mulai menggunakan kata-kata "kita" untuk menggantikan "Aku," dan "kita" bukan "aku." Anggota mungkin bahkan melekat satu sama lain, dan kadang-kadang, berlangsung sesuai kelompok. Meskipun orang "menganggap usaha patungan" melalui konvergensi simbolis, penting untuk menekankan bahwa ada batasan pada seberapa banyak hal yang sesuai dan harus dilakukan. 


\section{B. Teori Interaksi Simbolik}

Sejarah Teori Interaksionisme Simbolik tidak bisa dilepaskan daripemikiran George Herbert Mead (1863-1931). Mead membuatpemikiran orisinal yaitu "The Theoretical Perspective" yangmerupakan cikal bakal "Teori Interaksi Simbolik". Dikarenakan Meadtinggal di Chicago selama lebih kurang 37 tahun, maka perspektifnyaseringkali disebut sebagai Mahzab Chicago.

Dalam terminologi yang dipikirkan Mead, setiap isyarat non verbaldan pesan verbal yang dimaknai berdasarkan kesepakatan bersamaoleh semua pihak yang terlibat dalam suatu interaksi merupakan satubentuk simbol yang mempunyai arti yang sangat penting.

Perilaku seseorang dipengaruhi oleh simbol yang diberikan oleh oranglain, demikian pula perilaku orang tersebut. Melalui pemberian isyaratberupa simbol, maka kita dapat mengutarakan perasaan, pikiran,maksud, dan sebaliknya dengan cara membaca simbol yangditampilkan oleh orang lain.

Sesuai dengan pemikiran-pemikiran Mead, definisi singkat dari tiga ide dasar dari interaksi simbolik adalah :

a. Mind (pikiran) - kemampuan untuk menggunakan simbol yangmempunyai makna sosial yang sama, dimana tiap individuharus mengembangkan pikiran mereka melalui interaksidengan individu lain.

b. Self (diri pribadi) - kemampuan untuk merefleksikan diri tiapindividu dari penilaian sudut pandang atau pendapat orang lain,dan teori interaksionisme simbolis adalah salah satu cabangdalam teori sosiologi yang mengemukakan tentang diri sendiri(theself) dan dunia luarnya.

c. Society (masyarakat) - hubungan sosial yang diciptakan,dibangun, dan dikonstruksikan oleh tiap individu ditengahmasyarakat, dan tiap individu tersebut terlibat dalam perilakuyang mereka pilih secara aktif dan sukarela, yang padaakhirnya mengantarkan manusia dalam proses pengambilanperan di tengah masyarakatnya.

Tiga tema konsep pemikiran George Herbert Mead yang mendasari interaksi simbolik antara lain:

1. Pentingnya makna bagi perilaku manusia,

Tema ini berfokus pada pentingnya membentuk makna bagiperilaku manusia, dimana dalam teori interaksi simbolik tidakbisa dilepaskan dari proses komunikasi, karena awalnya maknaitu tidak ada artinya, sampai pada akhirnya di konstruksi secarainterpretif oleh individu melalui proses interaksi, untukmenciptakan makna yang dapat disepakati secara 
bersamadimana asumsi-asumsi itu adalah sebagai berikut : Manusia, bertindak, terhadap, manusia, lainnyaberdasarkan makna yang diberikan orang lain kepadamereka, Makna diciptakan dalam interaksi antar manusia, Makna dimodifikasi melalui proses interpretif

\section{Pentingnya konsep mengenai diri (self concept)}

Tema ini berfokus pada pengembangan konsep diri melaluiindividu tersebut secara aktif, didasarkan pada interaksisosial dengan orang lainnya dengan cara antara lain : Individu-individu mengembangkan konsep diri melalui nteraksi dengan orang lain, Konsep diri membentuk motif yang penting untuk perilaku Mead seringkali menyatakan hal ini sebagai : "The particularkind of role thinking - imagining how we look to anotherperson" or "ability to see ourselves in the reflection ofanother glass".

3. Hubungan antara individu dengan masyarakat.

Tema ini berfokus pada dengan hubungan antara kebebasanindividu dan masyarakat, dimana norma-norma sosialmembatasi perilaku tiap individunya, tapi pada akhirnya tiapindividu-lah yang menentukan pilihan yang ada dalam sosialkemasyarakatannya. Fokus dari tema ini adalah untukmenjelaskan mengenai keteraturan dan perubahan dalamproses sosial. Asumsi-asumsi yang berkaitan dengan temaini adalah : Orang dan kelompok masyarakat dipengaruhi oleh proses budaya dan sosial, Struktur sosial dihasilkan melalui interaksi sosial

\section{Teori Konvergensi Simbolik}

Bormann (1985) menyatakan bahwa teorinya dibangun dalam kerangka paradigma naratif yang meyakini bahwa manusia merupakan Homo Narrans. Yakni, mahluk yang saling bertukar cerita atau narasi yang menggambarkan pengalaman dan realitas sosialnya. Vasquez menjelaskan bahwa Homo Narrans berprinsip dasar bahwa manusia merupakan yang berbagi fantasi, membentuk kesadaran kelompok dan menciptakan realitas social. TKS menegaskan, solidaritas dan kohesifitas kelompok dapat dicapai melalui kecakapan bersama dalam membaca dan menafsirkan tanda-tanda, kode-kode dan teksteks budaya. Hal ini mengarahkan pada terbentuknya realitas bersama (shared reality) (Venus,2007.)

Sebagai teori berparadigma naratif, penelitian yang menerapkan teori ini mementingkan pengumpulan data interpretif ketimbang data kuantitatif, sebagaimana 
dikembangkan dalam teori berparadigma rasional. Berhubung sifatnya yang sedemikian, maka metode penelitian yang umumnya digunakan dalam kerangka paradigma ini mencakup studi kasus, analisa retoris atas catatan dan dokumen kelompok, serta analisa terhadap berbagai cerita yang berkembang di dalam dan di antara anggota suatu kelompok.

Watson dan Hill (2000) menjelaskan perbedaan paradigma rasional dan narrative sebagai payung teori komunikasi, dengan membedakan keyakinan tentang realitas. Menurut paradigma rasional, realitas bersifat tunggal. Ada satu kebenaran bersifat obyektif yang dapat dijadikan pegangan untuk menilai dan menguji satu argumentasi dan logika. Karena keyakinan seperti itu, proponen paradigma ini menganggap fantasi sebagai sesuatu yang sangat penting dalam kehidupan manusia. Bagi mereka, fantasi tidak diartikan sebagai kebohongan, melainkan tindakan sadar yang kreatif dan imajinatif dalam memberikan makna terhadap berbagai peristiwa yang terjadi. Di sini fantasi memiliki kebenarannya sendiri, tergantung pada subyek yang mempercayainya. Paradigma naratif berkeyakinan bahwa realitas bersifat majemuk dan kebenaran di konstruksi secara intersubyektif.

Bormann menyatakan, TKS adalah teori umum (general theory) yang mengupas fenomena pertukaran pesan yang memunculkan kesadaran kelompok hingga berimplikasi pada hadirnya makna, motif dan perasaan bersama. Penjelasan Bormann tadi mungkin saja sulit dicerna, tapi maksudnya sederhana saja, yaitu teori ini berusaha menerangkan bagaimana orang-orang secara kolektif membangun kesadaran simbolik bersama melalui proses pertukaran pesan.

Kesadaran simbolik yang terbangun dalam proses tersebut kemudian menyediakan semacam makna, emosi dan motif untuk bertindak bagi orang-orang atau kumpulan orangyang terlibat di dalamnya. Sekumpulan individu ini dapat berasal dari kelompok orang yang telah saling mengenal dan berinteraksi dalam waktu yang relative lama. Bisa juga bersumber dari orang-orang yang tidak saling mengenal dan memiliki cara berbeda dalam menafsirkan lambing yang digunakan, tapi mereka kemudian saling berkomunikasi sehingga terjadi konvergensi, yang pada gilirannya menciptakan realitas simbolik bersama. Dengan demikian, proses konvergensi dapat muncul bukan hanya dalam kelompok kecil yang relative saling mengenal tetapi bisa juga terjadi pada rapat akbar, atau suatu saat seseorang mendengarkan ceramah, atau ketika kita menikmati film dan iklan politik di televise.

Dalam teori ini, Bormann (1990) mengartikan istilah konvergensi (convergence) sebagai suatu cara dimana dunia simbolik pribadi dari dua atau lebih individu saling bertemu, saling mendekati satu sama lain, atau kemudian saling berhimpitan (the way in which the 
private symbolic worlds of two or more people begin come together or overlap). Sedangkan istilah simbolik itu sendiri terkait dengan kecenderungan manusia untuk memberikan penafsiran dan menanamkan makna kepada berbagai lambang, tanda, kejadian yang tengah dialami, atau bahkan tindakan yang dilakukan manusia (Bormann, 1986). Dalam kaitan ini Bormann juga menyatakan bahwa manusia adalah symbol users, dalam arti bahwa manusia menggunakan symbol dalam komunikasi secara umum maupun dalam storytelling. Ketika kelompok berbagi symbol bersama, komunikasi menjadi lebih mudah dan efisien. Para ahli TKS menganggap a meeting of mind). Ketika pikiran saling bertemu maka orang mulai bergerak kearah penggunaan system symbol yang sama.

Saling pengertian tersebut kemudian menjadi dasar terciptanya kesadaran bersama, serta kesamaan pikiran, perasaan, tentang hal-hal yang diperbincangkan. Bormann (1985) menyebutkan tiga aspek atau struktur penting yang membentuk bangunan teori ini yakni: (1) Penemuan dan penataan bentuk serta pola komunikasi berulang yang mengindikasikan hadirnya kesadaran bersama dalam kelompok secara evolutif, (2) Deskripsi tentang kecenderungan dinamis dalam system komunikasi yang menerangkan mengapa kesadaran kelompok muncul, berlanjut, menurun, dan pada akhirnya menghilang, (3) Faktor-faktor yang menerangkan mengapa orangoranf terlibat dalam tindakan berbagi fantasi.

Disamping itu terdapat dua (2) asumsi pokok yang menjadi dasar Teori Konvergensi Simbolik. Pertama, realitas diciptakan melalui komunikasi. Dalam hal ini, komunikasi menciptakan realitas melalui pengaitan antara kata-kata yang digunakan dengan pengalaman atau pengetahuan yang diperoleh. Kedua, makna individual terhadap symbol dapat mengalami konvergensi (penyatuan), sehingga menjadi realitas bersama. Realitas dalam teori ini dipandang sebagai susunan narasi atau cerita-cerita yang menerangkan bagaimana sesuatu harus dipercayai oleh orang-orang yang terlibat di dalamnya. Cerita tersebut bermula diperbincangkan dalam lingkungan kelompok, kemudian disebarkan ke lingkungan masyarakat yang lebih luas. Menyertai kedua asumsi tersebut.

Bormann (1986) juga menyebutkan asumsi epistemologis teori ini, yaitu: (1) Makna, emosi dan motif bertindak ada pada isi pesan yang ternyatakan dengan jelas; (2) Realitas diciptakan secara simbolik; (3) Rantai fantasi menciptakan konvergensi simbolik dalam bentuk dramatistik; (4) Analisa tema fantasi adalah metode pokok dalam menangkap realitas simbolik; (5) Tema fantasi dapat terjadi dalam berbagai wacana yang dikembangkan dan terakhir, (6) Terdapat tiga visi analog master, yaitu righ-teous, social dan pragmatic. 
Bormann menyebut metode untuk mengoperasionalkan teorinya dengan istilah Fantasy Theme Analysis (FTA), sebagaimana memahami teori ini perlu kita pahami istilahistilah kunci dalam ATF, yaitu :

\section{Fantasy Theme ( Tema Fantasi)}

Bormann mendefinisikan tema fantasi sebagai isi pesan yang didramatisasi hingga memicu rantai fantasi (the content of the dramatizing message that sparks the fantasy chain). Menurut Miller (2002), fantasy theme (tema fantasi), yang diartikan sebagai dramatisasi pesan, dapat berupa lelucon, analogi, permainan kata, cerita, dan sebagainya, yang memompa semangat berinteraksi.Dramatisasi pesan tidak terjadi dalam konteks tugas atau pekerjaan yang tengah dihadapi. Dramatisasi pesan juga tidak terjadi ala tindakan komunikasi yang membicarakan tindakan atau kegiatan bersama yang terjadi pada saat peristiwa berlangsung, tidak memiliki muatan imajinatif. Pembicaraan tersebut bersifat nyata karena berkaitan dengan aspek nyata karena berkaitan dengan aspek -mata membicarakan tugas atau kegiatan yang tengah dihadapi kelompok.

Akan lain halnya, bila anda memperbincangkan peristiwa yang terjadi di luar kelompok. Atau membicarakan peristiwa serupa yang dialami anggota kelompok masa lalu. Atau berbicara tentang sesuatu yang terkait dengan masa depan. Hal-hal semacam itu dapat

dikategorikan sebagai fantasi. Konflik dalam pertemuan kelompok, misalnya mungkin dilihat sebagai peristiwa dramatis. Namun ini bukanlah dramatisasi pesan atau tema fantasi, berhubung hal itu

\section{Fantasy Chain (rantai fantasi)}

Secara harfiah, fantasy chain diartikan sebagi rantai fantasi. Maksudnya, ketika pesan yang didramatisasi berhasil mendapat tanggapan dari partisipan komunikasi , hingga meningkatkan intensitas dan kegairahan partisipan dalam berbagi fantasi. Ketika fantasi yang berkembang, maka terjadilah rantai fantasi. Ketika rantai fantasi tercipta, tempo percakapan jadi meningkat, antusiasme partisipan muncul, dan timbul peningkatan rasa empati danumpanbalik di antara partisipan komunikasi.

Bormann (1990) sendiri menggambarkan rantai fantasi sebagai Rantai fantasi membawa partisipan saling berbagi cerita ke dalam konvergensi simbolik. Rantai fantasi menciptakan landasan pengertian bersama sehingga membuat kelompok mempu mencapai komunikasi yang empatik, sekaligus menghindarkan a meeting of mind. 


\section{Fantasy Type (Tipe Fantasi)}

Bormann mengartikan konsep ini sebagai tema-tema fantasi yang berulang dan dibicarakan pada situasi yang lain, dengan karakter yang lain, dengan karakter yang lain, dan latar yang lain, namun dalam alur cerita yang sama. Jika kerangka narasi (the narrative frame) sama, tetapi tokoh, karakter, atau settingnya berbeda, maka tema tersebut dapat dikelompokkan dalam satu jenis fantasi yang sama. Sementara, bila terdapat beberapa tema fantasi, atau kerangka narasi yang berbeda, itu berarti terdapat beberapa tipe fantasi.

Menurut Trenholm (1986 dalam Venus, 2007), tipe fantasi adalah kerangka narasi bersifat umum yang terkait dengan pertanyaan atau masalah tertentu. Mereka yang telah beinteraksi lama akan mengembangkan semacam symbolic cue atau petunjuk simbolis yang biasanya telah dipahami bersama. Symbolic cue biasanya menjadi inside joke (lelucon yang hanya dipahami oleh orang-orang yang terlibat dalam percakapan sebelumnya). Di kelas bisa jadi akan ditertawai ramai-ramai karena bagi sebagian sebelah.

Bormann (1990) juga membandingkan suatu tipe fantasi yang seringkali terulang dalam kultur sebuah kelompok. Partai politik di Amerika Serikat, misalnya menjaga kesatuannya dengan tipe fantasi yang sama. Partai Republik dinilai sebagai partai konservatif, digerakkan oleh dan untuk kepentingan perusahaan-perusahaan besar, serta tidak berpihak kepada buruh dan rakyat miskin. Seementara Partai Demokrat dianggap sebagai partai yang terlalu liberal, tidak bertanggungjawab secara fiscal, pencipta inflasi, ketidakseimbangan anggaran dan kekacauan ekonomi.

\section{Rhetorical Visions (Visi retoris)}

Visi retoris diartikan types across under a wi Di sini tema-tema fantasi itu telah berkembang dan melebar keluar dari kelompok yang mengembangkan fantasi tersebut pada awalnya. Karena perkembangan tersebut, maka tema-tema fantasi itu menjadi fantasi mesyarakat luas dan membentuk semacam rhetorical community (komunitas retoris). Salah satu contoh yang dikemukakan Heisey and Trebing dalam konteks negarabangsa, dua visi retoris yang bertentangan dibahas pada revolusi Shah Iran yang terjadi antara tahun 1978 sampai 1979. Visi retoris sosial yang dikembangkan oleh Revolusi Putih Shah (faksi politik penguasa) adalah perdamaian global yang salingbergantung dengan Barat melalui kemajuan teknologi dan pertumbuhan masayarakat. Visi retoris yang benar dari revolusioner Islam Ayatullah (faksi politik oposisi penantang) didasarkan pada sikap bertentangan dengan Barat, ketaatan pada Alkekuatan Islam dan membersihkannya dari kontaminasi nilai-nilai Barat 
(westoxicity). Perang analogi utama itu (Cragan \& Shields, 1981) mencapai puncak dalam konfrontasi politik yang kemudian merubah kesadaran masyarakat Iran. (Olufowote, 2006 )

Disamping keempat konsep kunci tersebut, Bormann juga menjelaskan bahwa dalam setiap analisis fantasi, atau kajian visi retoris yang lebih luas lagi, selalu terdapat empat elemen pokok berikut ; (1) Tokoh-tokoh terlibat (dramatic personae atau character); (2) Alur cerita (plot line); (3) Latar (scene) dan (4) Agen penentu kebenaran cerita (sanctioning agents). Tokoh pemeran dalam cerita itu dapat berupa pahlawan, penjahat dan pemain penudkung lainnya. Alur cerita merupakan rangkaian cerita yang kembangngkan, berikut tindakan-tindakan yang dilakukan. Pada aspek latar, tercakup lokasi, berbagai peralatan atau perlengkapan terkait, serta aspek sosiokultural dalam latar tersebut. Terakhir sanctioning agent yang akan menentukan dan melegitimasi kebenaran cerita. Kasus terorisme di Indonesia bisa menjadi contoh dalam hal ini.

Terorisme dalam berbagai kajian dianggap lahir sebagai jawaban dari adanya tekanan Barat terhadap kekuatan Islam diseluruh dunia. Perlakuan tidak adil pada umat Islam telah mendorong tindakan terorisme seperti bom bunuh diri serta tindakan terror lainnya yang dialamtkan pada kepentingan dunia Barat. Legitimasi tindakan mereka di dasarkan pada kepemimpinan Osama Bin Laden ataupun tokoh sentral disekitar mereka dengan mendasarkannya pada teks-teks agama yang menyangkut tindakan jihad.

Bormann (Morris \& Buchanan, 2000) menyebut keempat elemen tersebut sebagai dramatistic structural elements. Unsur-unsur tersebut terasa mirip dengan elemen-elemen pokok dalam teori Dramatisme Kenneth Burke. Metode untuk menganalisis dari Burke yaitu dramatistic Pentad.Pentad adalah kelompok yang terdiri dari lima unsur, yaitu: (1). Tindakan (apa yang diperbuat oleh pelakunya); (2). Tempat kejadian situasi atau tempat dicapainya kejadian itu; (3) Agensi sebagai alat atau kendaraan yang digunakan pelaku; (4). Maksud adalah alasan untuk bertindak-tujuan dan (5). Pengaruh atau hasil yang diharapkan dari tindakan tersebut.

Lebih lanjut Morris \& Buchanan (2000) menyatakan kajiankajian komunikasi bersifat humanistic cenderung menggunakan sudut pandang dramatistik. Empat tokoh terkemuka yang menggunakan sudut pandang ini adalah Kenneth Burke, Erving Goffman, Walter Fisher dan Ernest Bormann. 


\section{Penutup}

Teori interaksi simbolik di mana manusia atau indivuidu hidup dalam suatu lingkungan yang di penuhi oleh symbol-simbol.Tiap individu yang hidup akan memberikan tanggapan terhadap simbol-simbol yang ad Seperti penilaian individu menanggapi suatu rangsangan (stimulus) dari suatu yang bersifat fisik.Pemahaman individu terhadap symbolsimbol merupakan suatu hasil pembelajaran dalam berinteraksi di tengah masyarakat,Dengan mengkomunikasikan symbol-simbol yang ada di sekitar mereka,baik secara verbal maupun perilaku non verbal.Pada akhirnya,proses kemampuan berkomunikasi,belajar,serta memahami suatu makna di balik symbol-simbol yang ada,menjadi keistimewaan tersendiri bagi manusia di bandingkan makhluk hidup lainnya (binatang).Kemampuan manusia inilah yang menjadi pokok perhatian dari analisis sosiologi dari teori interaksi simbolik.Ciri khas dari interaksi simbolik terletak pada penekanan manusia dalam lansung antara stimulus response,tetapi di dasari pada pemahaman makna yang di berikan terhadap tindakan orang lain melalui penggunaan symbol-simbol,interpretasi,pada akhirnya tiap andividu tersebut akan berusaha saling memahami maksud dan tindakan masing-masing untuk mencapai kesepakatan bersama.

Penerapan teori TKS dalam bidang praktis dan akademis akhir-akhir ini semakin banyak. Hal ini tentu saja berkaitan dengan luasnya konteks komunikasi yang dapat dijangkau oleh teori ini. Jika kita menyimak dari segi konteks komunikasi, TKS dianggap sebagai teori umum yang dapat diterapkan dalam berbagai konteks komunikasi, seperti komunikasi antarpribadi, kelompok, organisasi, public ataupun komunikasi massa (Salwen \& Stack, 1996, Wood, 2000, Bormann, 1990). Sementara, bila dilihat dari bidang spesialisasi komunikasi, teori ini dapat diterapkan dalam kegiatan komunikasi politik, keluarga, pendidikan hingga komunikasi pemasaran.Secara tradisional teori ini banyak digunakan untuk menganalisis proses komunikasi dalam konteks kelompok, seperti aktivitas pembuatan keputusan dalam kelompok, budaya kelompok, identitas dan identifikasi kelompok, hingga peneguhan kohesivitas kelompok (Wilson \& Hanna, 1993; Venus, 2007). Dalam kaitannya dengan pembuatan keputusan dalam kelompok, Bormann menyatakan bahwa pertukaran fantasi kelompok merupakan bagian dari proses pembuatan keputusan. Dalam proses pembuatan keputusan kelompok, TKS memusatkan perhatiannya pada tiga aspek penting, yakni; (1) Pola-pola komunikasi yang menunjukkan kesadaran kelompok; (2) Menggambarkan bagaimana dan mengapa kesadaran kelompok berubah dan (3) Menjelaskan mengapa orang berbagi fantasi. 


\section{DAFTAR PUSTAKA}

Venus, Antar. Ernest Bormann dan Teori Konvergensi Simbolik. Bandung, Jurnal ISKI, 2007.

Em Griffin, A First Look At Communication Theory, ed. 5th, New York: McGraw-Hill Companies, 1991.

Littlejohn, Stephen.W. Theories of Human Communication.7 Edh. Wadsworth.2002

Olufowote,James O. Rousing And Redirecting A Sleeping Giant (Symbolic Convergence Theory And Complexities In The Communicative Constitution Of Collective Action). Management Communication Quarterly, Vol. 19, No. 3, February 2006. Boston College, Chestnut Hill, 2006.

Venus, Antar. Ernest Bormann dan Teori Konvergensi Simbolik. Jurnal ISKI Bandung Vol.1 No.1 Agustus 2007.

Young, Denise. Bormann's Symbolic Convergence Theory (Paper). University of Colorado, 1998 